\title{
ANALISIS KOMPETENSI PEDAGOGI KE-PLB-AN GURU BERDASARKAN INTENSITAS KEIKUTSERTAAN PELATIHAN PENDIDIKAN ANAK BERKEBUTUHAN KHUSUS DI SEKOLAH INKLUSI
}

\author{
Tias Martika, Abdul Salim, Munawir Yusuf
}

Pendidikan Luar Biasa, Fakultas Keguruan dan Ilmu Pendidikan, Universitas Sebelas Maret tiasmartika@gmail.com, salimchoiri@fkip.uns.ac.id,munawir uns@yahoo.co.id

\begin{abstract}
Abstrak
Penelitian ini bertujuan untuk memetakan kompetensi guru di sekolah inklusi berdasarkan keikutsertaan guru dalam mengikuti pelatihan tentang pendidikan inklusi. Subjek penelitian ini yaitu guru kelas di sekolah inklusi. Teknik pengambilan sampel yaitu purposive random sampling dengan jumlah sampel 38 guru. Teknik pengumpulan data dengan menggunakan instrumen pengukuran kompetensi dengan nilai reliabilitas 0.91. Hasil yang diperoleh kemudian dianalisis menggunakan anova one way. Hasil statistik deskriptif menunjukkan bahwa dari jumlah subjek 38 responden nilai rata (mean) 61,50 nilai terendah (minimum) 40 dan nilai tertinggi (maximum) 88. Sedangkan hasil analisis Anova One Way kompetensi guru menunjukkan $\mathrm{P}(\mathrm{P}-\mathrm{value})=0,000$. P-Value $0,000<0,05$ dan F-Value $>\mathrm{F}$ Tabel 24,993 $>3,27$ disimpulkan ada perbedaan yang signifikan kompetensi pedagogik guru berdasarkan keikutsertaan pelatihan inklusi yang telah diikuti. Kebutuhan guru dalam pelatihan tentang pendidikan inklusi pada sejumlah 38 responden yaitu, $61 \%$ sangat perlu, $37 \%$ perlu, dan $3 \%$ tidak perlu. identifikasi kebutuhan materi pelatihan pendidikan inklusi sebagai berikut 1) pengertian anak berkebutuhan khusus, 2) Jenis anak berkebutuhan khusus, 3) karakteristik anak berkebutuhan khusus, 4) Identifikasi ABK, 5) adaptasi kurikulum bagi ABK, 6) Program Pembelajaran Individual (PPI), 7) Strategi pembelajaran bagi ABK, 8) Evaluasi pembelajaran ABK, 9)Peraturan Menteri Pendidikan Nasional Nomor 70 tahun 2009, 10) Pengertian full inklusi dan segregasi, dan 11) tugas guru pembimbing khusus di sekolah inklusi.
\end{abstract}

Kata Kunci: Kompetensi, Guru, Sekolah Inklusi, Pelatihan

\begin{abstract}
The study aims to map the competency of teachers in the inclusion school based on teacher participation in training on inclusion education. The subject of this study is teacher grade an inclusion school. Sampling technique is purposive random sampling with a sample number of 38 teachers - data collection techniques using competency measurement instruments with a reliability value of 0.91 . The results obtained are then analyzed using Anova one way. The descriptive statistical results indicate that from the subject number of 38 respondents, the average value (mean) 61.50 the lowest value (minimum) 40 and the highest value (maximum) 88. While the analysis results of Anova One Way The teacher's competency suggests $\mathrm{P}$ (P-value) $=0.000$. P-Value $0.000<0.05$ and F-Value $>\mathrm{F}$ table $24.993>3.27$ concluded there are significant differences in pedagogic competence of teachers based on the participation of inclusion training that has been followed. The teacher's need in training on inclusion education on a number of 38 respondents is, $61 \%$ is necessary, $37 \%$ is necessary, and $3 \%$ is unnecessary. Identification of material needs education training inclusion as follows 1) understanding children with disabilities, 2) types of children with special needs, 3) characteristics of children with special needs, 4) Identification of $A B K, 5)$ adaptation curriculum for ABK, 6) Program Individual Learning (PPI), 7) Learning strategy for the ABK, 8) evaluation of the ABK Learning, 9) Regulation
\end{abstract}


of the Minister of National Education No. 70 the year 2009, 10) Understanding of full inclusion and segregation, and 11) the assignment of special guidance teachers in inclusion schools.

Keywords: Competence, teachers, inclusion school, training

\section{PENDAHULUAN}

Berbagai regulasi mengenai pendidikan di Indonesia diantaranya UU No. 4 Th. 1997 tentang penyandang cacat, pasal 5 dinyatakan "setiap penyandang cacat mempunyai hak dan kesempatan yang sama dalam segala apek kehidupan dan penghidupan". Serta mengacu pada UUD 1945 (amandemen) pasal 31 ayat (1) :"Setiap warga negara berhak mendapatkan pendidikan". Arah pendidikan di Indonesia mulai bergeser dari segregasi menuju inklusi. Menurut PP No. 70 Tahun 2009 pasal 1 dijelakan bahwa pendidikan inklusif adalah sistem penyelenggaraan pendidikan yang memberikan kesempatan pada semua peserta didik yang memiliki kelainan dan memiliki potensi kecerdasan dan/atau bakat istimewa untuk mengikuti pendidikan atau pembelajaran dalam lingkungan pendidikan secara bersama-sama dengan peserta didik pada umumnya.

Anak disabilitas

(ABK) memiliki hambatan dalam mengikuti pembelajaran, hambatan itu mulai dari gradasi paling berat sampai dengan yang paling ringan. Bagi peserta didik yang memiliki hambatan berat, mereka dididik di Sekolah Luar Biasa (SLB) dan Sekolah Dasar Luar Biasa (SDLB). Sedangkan yang memiliki hambatan belajar pada gradasi sedang dan ringan dapat dididik di sekolah http://doi.org/10.31537/speed.v3i2.274 umum/sekolah regular. Pendidikan bagi ABK di sekolah umum/sekolah regular disebut pendidikan inklusif. Tujuan pendidikan inklusif antara lain untuk mengatasi keterbatasan jumlah SLB dan SDLB yang telah ada (karena SLB dan SDLB baru mampu mendidik 1\% dari ABK usia sekolah) serta untuk mempercepat pencapaian program wajib belajar.

Pendidikan inklusif di Indonesia sudah dirintis sejak tahun 2003. Berdasarkan SE Dirjen Dikdasmen Depdiknas No.380 /C.66/MN/2003, 20 Januari 2003, yang dipertegas Permendiknas No.70 Tahun 2009. Sampai akhir tahun 2010 di Indonesia telah dirintis sebanyak 900 sekolah inklusif dengan perincian sebanyak 698 sekolah jenjang SD, 101 sekolah jenjang SMP dan 101 sekolah jenjang SMA/SMK. Data yang ada di Direktorat Pembinaan PKLK Dikdas (2013), menunjukkan bahwa jumlah sekolah inklusi di Indonesia pada tahun 2007 sekitar 925 satuan pendidikan (SD, SMP, SMA, dan SMK) dan meningkat pada tahun 2013 menunjukkan sejumlah 2.100 satuan pendidikan.

Meskipun semakin tahun jumlah sekolah yang menyelenggarakan program inklusif meningkat namun pelaksanaan sekolah inklusif belum sepenuhnya sesuai dengan target sekolah inklusif yang diinginkan. Aspek-aspek penyelenggaraan sekolah 
inklusif dalam Munawir (2014) menyebutkan aspeek-aspek sekolah inklusi yaitu : 1). Aspek kelembagan; 2) Aspek kurikulum dan pembelajaran; 3) Aspek kesiswaan; 4) Aspek ketenagaan (SDM); 5) Aspek sarana dan prasarana; 6) Aspek peran serta masyarakat; 7) Aspek pembiayaan. Dari aspek-aspek yang disebutkan di atas, penyelenggara sekolah inklusif masih memiliki banyak kendala dalam pelaksanaannya.

Pelaksanaan program inklusif perlu adanya monitoring dan evaluasi guna meningkatkan kualitas penyelenggaraan program inklusif di sekolah-sekolah inklusi. Serta untuk mewujudkan tujuan pendidikan inklusif yang tertera pada PP No. 70 tahun 2009 pasal 2, pendidikan inklusif bertujuan :

a. Memberikan kesempatan yang seluas-luasnya kepada semua peserta didik yang memiliki kelainan fisik, emosional, mental, dan sosial, atau memiliki potensi kecerdasan dan/atau bakaat istimewa untuk memperolehpendidikan yang bermutu sesuai dengan kebutuhan dan kemampuannya;

b. Mewujudkan penyelenggaraan pendidikan yang menghargai keanekaragaman, dan tidak diskriminatif bagi semua peserta didik sebagaimana yang dimaksud pada huruf a.

http://doi.org/10.31537/speed.v3i2.274
Dalam implementasi sekolah inklusi, banyak hambatan yang terjadi baik yang berkaitan kurikulum, kemampuan guru, sarana dan prasarana, sampai dalam hal penilaian. Dengan ditingkatkannya kompetensi guru dalam keterampilan pengembangan kemampuan kemandirian anak disabilitas untuk sekolah inklusi" ini diharapkan dapat mengeliminasi permasalahanpermasalahan di sekolah inklusi di Indonesia.

\section{METODE}

Jenis penelitian yang digunakan dalam penelitian ini yaitu dengan pendekatan Kuantitatif. Menurut Sugiyono (2014, hlm. 14) metode penelitian kuantitatif dapat diartikan sebagai metode penelitian yang berlandaskan pada filsafat positivisme digunakan untuk meneliti pada populasi atau sampel tertentu, teknik pengambilan sampel pada umumnya dilakukan secara random, pengumpulan data menggunakan instrumen penelitian analisis data bersifat kuantitatif/statistik dengan tujuan menguji hipotesis yang telah ditetapkan

Sedangkan metode yang digunakan menggunakan metode survei. Menurut Zikmund (1997) "metode penelitian survei adalah satu bentuk teknik penelitian di mana informasi dikumpulkan dari sejumlah sampel berupa orang, melalui pertanyaan-pertanyaan", menurut Gay \& Diehl (1992) "metode penelitian survei merupakan metode yang digunakan sebagai kategori umum penelitian yang menggunakan 
kuesioner dan wawancara", sedangkan menurut Bailey (1982) "metode penelitian survei merupakan satu metode penelitian yang teknik pengambilan datanya dilakukan melalui pertanyaan - tertulis atau lisan"

Subjek penelitian ini yaitu guru kelas di sekolah inklusi. Teknik pengambilan sampel dilakukan dengan cara random. Karena populasi pada penelitian ini dianggap homogen maka cara random yang digunakan adalah Simple Random Sampling yang dilakukan dengan random numbers (Zainuddin, 2000) dengan jumlah sampel 38 guru. Teknik pengumpulan data dengan menggunakan instrumen pengukuran kompetensi dengan nilai reliabilitas 0.91 . Hasil yang diperoleh kemudian dianalisis menggunakan analisis anova (analysis of variance).

\section{HASIL DAN PEMBAHASAN}

Berdasarkan penelitian yang dilakukan diperoleh hasil sebagai berikut:

a. Tingkat kompetensi guru di sekolah inklusi

Hasil pengukuran tingat

kompetensi guru di sekolah inklusi tingkat sekolah dasar sebagai berikut

Tabel 1. Skor kemampuan kompetensi pedagogic ke-PLB-an guru di sekolah inklusi

\begin{tabular}{|c|c|c|c|}
\hline Subjek & $\begin{array}{c}\text { Score kemampuan } \\
\text { kompetensi } \\
\text { pedagogik }\end{array}$ & $\begin{array}{c}\text { Intensitas dalam } \\
\text { mengikuti peltihan } \\
\text { inklusi }\end{array}$ & Kriteria \\
\hline 1 & 70 & 1 & Baik \\
\hline 2 & 74 & 0 & Baik \\
\hline 3 & 64 & 1 & Baik \\
\hline 4 & 88 & 3 & Sangat Baik \\
\hline 5 & 56 & 0 & Cukup \\
\hline 6 & 58 & 1 & Cukup \\
\hline 7 & 58 & 0 & Cukup \\
\hline 8 & 48 & 0 & Cukup \\
\hline 9 & 71 & 1 & Baik \\
\hline 10 & 73 & 1 & Baik \\
\hline 11 & 73 & 0 & Baik \\
\hline 12 & 59 & 0 & Cukup \\
\hline 13 & 44 & 0 & Cukup \\
\hline 14 & 79 & 1 & Baik \\
\hline 15 & 42 & 0 & Cukup \\
\hline 16 & 52 & 0 & Cukup \\
\hline 17 & 54 & 0 & Cukup \\
\hline 18 & 40 & 0 & Kurang \\
\hline 19 & 40 & 0 & Kurang \\
\hline 20 & 44 & 0 & Cukup \\
\hline 21 & 56 & 0 & Cukup \\
\hline 22 & 70 & 1 & Baik \\
\hline 23 & 54 & 0 & Cukup \\
\hline 24 & 71 & 1 & Baik \\
\hline 25 & 69 & 1 & Baik \\
\hline 26 & 69 & 1 & Baik \\
\hline 27 & 69 & 1 & Baik \\
\hline
\end{tabular}


Volume 3, No. 2 Januari 2020

\begin{tabular}{cccc}
\hline Subjek & $\begin{array}{c}\text { Score kemampuan } \\
\text { kompetensi } \\
\text { pedagogik }\end{array}$ & $\begin{array}{c}\text { Intensitas dalam } \\
\text { mengikuti peltihan } \\
\text { inklusi }\end{array}$ & Kriteria \\
\hline 28 & 71 & 1 & Baik \\
\hline 29 & 77 & 2 & Baik \\
\hline 30 & 53 & 1 & Cukup \\
\hline 31 & 46 & 0 & Cukup \\
\hline 32 & 55 & 0 & Cukup \\
\hline 33 & 61 & 1 & Baik \\
\hline 34 & 50 & 0 & Cukup \\
\hline 35 & 61 & 1 & Baik \\
\hline 36 & 59 & 0 & Bukup \\
\hline 37 & 74 & 2 & Sangat Baik \\
\hline 38 & 85 & 3 & SPS \\
\hline
\end{tabular}

Berdasarkan data diatas kemudian dioah menggunakan SPSS 20 dengan hasil sebagai berikut:

\begin{tabular}{|l|r|r|r|r|r|}
\hline & \multicolumn{1}{|c}{ Descriptive Statistics } \\
\hline Pedagogy & 38 & 61,50 & 12,580 & 40 & 88 \\
\hline
\end{tabular}

Hasil statistik deskriptif diatas menunjukkan bahwa dari jumlah subjek 38 responden nilai rata (mean) 61,50, nilai terendah (minimum) 40, dan nilai tertinggi (maximum) 88 .

$$
\text { Kemampuan kompetensi }
$$
pedagogik ke PLB an guru di sekolah inklusi memang belum sepenuhnya sangat memahami. Hal ini dikarenakan berbagai faktor diantaranya latar belakang Pendidikan, pengalaman menangani anak berkebutuhan khusus, minat pada anak berkebutuhan khusus juga pelatihan dan kegiatan-kegiatan lain yang menyangkut ke PLB an seperti seminar, workshop, lokakarya dll.

Penelitian yang dilakukan oleh Gunarhadi dkk (2016) dengan judul Pedagogic mapping of teacher competence in inclusive schools hasil penelitian menunjukkan bahwa kebanyakan guru di sekolah inklusi memiliki kemampuan dan keterampilan yang rendah. Guru tidak hanya memiliki pengalaman mengajar yang kurang tetapi juga masih rendahnya kualitas pendidikan dalam menangani siswa berkebutuhan khusus.

Normality test

One-Sample Kolmogorov-Smirnov Test

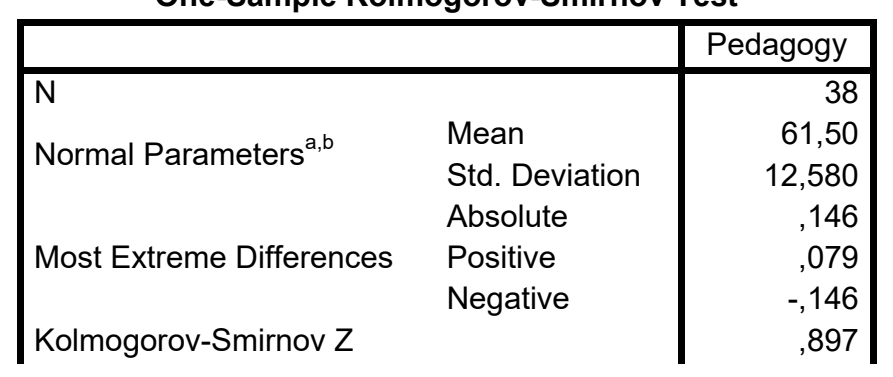


Volume 3, No. 2 Januari 2020

Asymp. Sig. (2-tailed) ,397

a. Test distribution is Normal.

b. Calculated from data.

Berdasarkan tabel diatas , menunjukkan nilai signifikansi 0,397. menunjukkan bahwa hasil tes Karena $\mathrm{P}=$ Value $0,397>0,05$, maka normalitas dengan menggunanakan data merupakan dari sampel yang kolmogorov-Smirnov test berdistribusi normal.

Tes Homogenitas

Test of Homogeneity of Variances

Pedagogy

\begin{tabular}{|c|c|c|c|}
\hline Levene Statistic & df1 & df2 & Sig. \\
\hline ,799 & 2 & 35 & ,458 \\
\hline
\end{tabular}

Berdasarkan tabel diatas menunjukkan bahwa nilai signifikansi yaitu 0,458 . data berasal dari sampel yang Karena P-Value 0,458 $>0,05$ maka homogen.

Tes Anova One Way ANOVA

Pedagogy

\begin{tabular}{|l|r|r|r|r|r|}
\hline & Sum of Squares & df & Mean Square & F & Sig. \\
\hline Between Groups & 3444,040 & 2 & 1722,020 & 24,993 &, 000 \\
Within Groups & 2411,460 & 35 & 68,899 & & \\
Total & 5855,500 & 37 & & & \\
\hline
\end{tabular}

Berdasarkan hasil uji Anova One Way di atas dapat diketahi bahwa diperoleh didapatkan adalah ada perbedaan nilai $\mathrm{P}(\mathrm{P}$-value $)=0,000$. P-Value $0,000<0,05$ dan F-Value $>$ F Tabel yang signifikan kompetensi pedagogik guru berdasarkan keikutsertaan pelatihan inklusi yang telah diikuti.

$24,993>3,27$ maka kesimpulan yang

\section{Multiple Comparisons}

Dependent Variable: Pedagogy

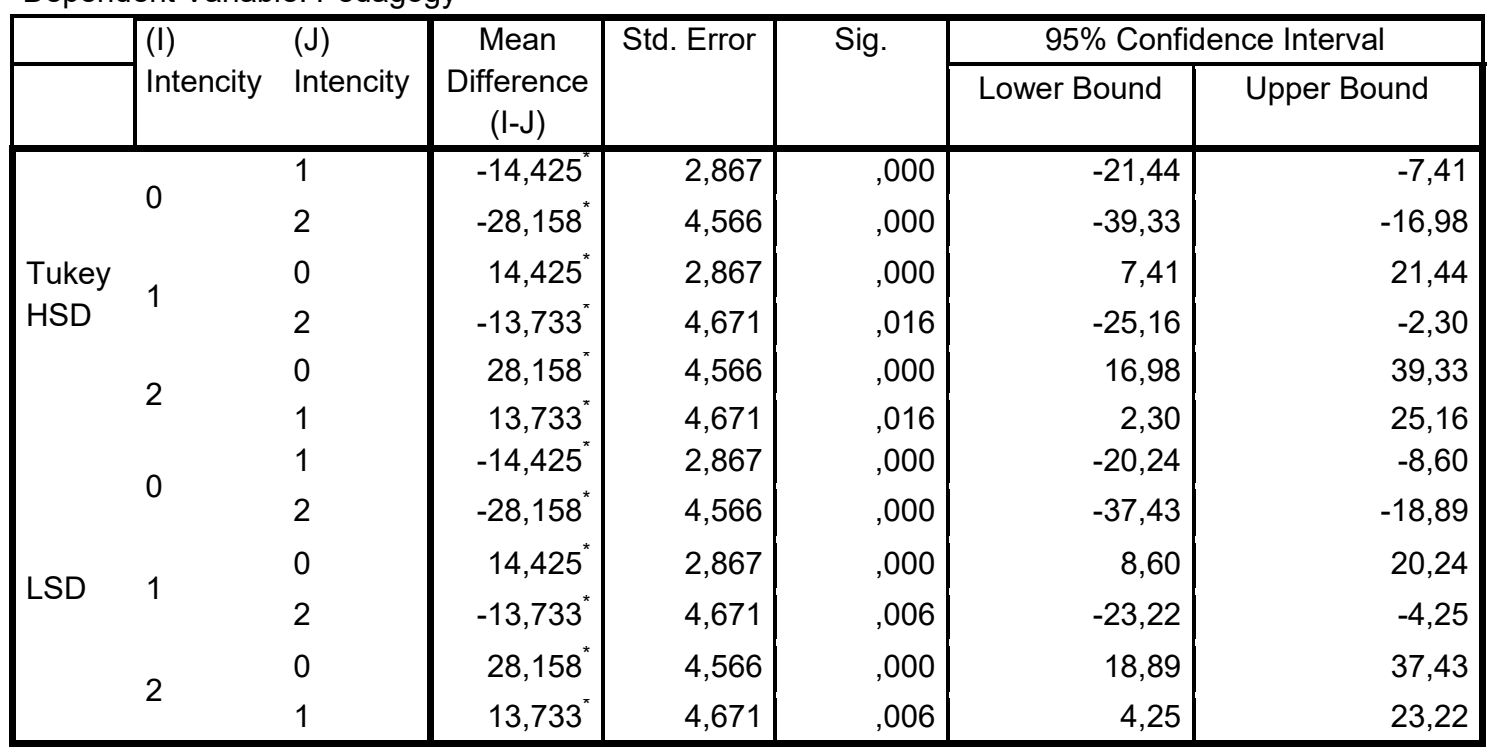

*. The mean difference is significant at the 0.05 level.

Hasil survei yang telah diperoleh

kemudiaan dikembangkan untuk

http://doi.org/10.31537/speed.v3i2.274 
Volume 3, No. 2 Januari 2020

mengetahui tingkat kebutuhan guru

dan diperoleh data sebagai berikut

dalam pelatihan pendidikan inklusi

Tabel. 2 Tingkat Kebutuhan Guru Dalam Pelatihan Pendidikan Inklusi

\begin{tabular}{lcc}
\hline $\begin{array}{c}\text { Kebutuhan } \\
\text { Pelatihan }\end{array}$ & Jumlah & Presentase \\
\hline Sangat Perlu & 23 & $61 \%$ \\
\hline Perlu & 14 & $37 \%$ \\
\hline Kurang perlu & 0 & $0 \%$ \\
\hline Tidak perlu & 1 & $3 \%$ \\
\hline JUMLAH & 38 & $100 \%$ \\
\hline
\end{tabular}

Berdasarkan tabel di atas dapat

yaitu, $61 \%$ sangat perlu, $37 \%$ perlu, diketahui mengenai kebutuhan guru dalam pelatihan tentang pendidikan inklusi pada sejumlah 38 responden dan 3\% tidak perlu. Data tersebut dapat disajikan dalam diagram dibawah ini:

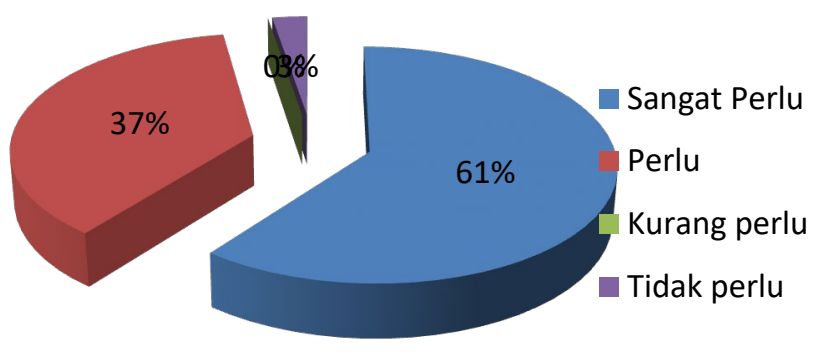

Gambar 1. Tingkat Kebutuhan Guru Dalam Pelatihan Pendidikan Inklusi

Hasil tersebut sejalan dengan penelitian yang dilakukan Elisa (2013) yang menyatakan bahwa faktor pengetahuan guru mengenai anak berkebutuhan khusus sangat diperlukan untuk membentuk sikap gurur terhadap Pendidikan inklusi diantaranya meliputi tingkat pendidikan, pelatihan, pengetahuan dan kebutuhan belajar guru.

Lebih dalam lagi penelitian ini mengidentifikasi kebutuhan materi pelatihan pendidikan inklusi dapat diperoleh data sebagai berikut:

1. Pengertian anak berkebutuhan khusus, http://doi.org/10.31537/speed.v3i2.274
2. Jenis anak berkebutuhan khusus,

3. Karakteristik anak berkebutuhan khusus,

4. Identifikasi ABK,

5. Adaptasi kurikulum bagi ABK,

6. Program Pembelajaran Individual (PPI),

7. Strategi pembelajaran bagi $\mathrm{ABK}$,

8. Evaluasi pembelajaran ABK,

9. Peraturan Menteri Pendidikan Nasional Nomor 70 tahun 2009, 
Volume 3, No. 2 Januari 2020

10. Pengertian full inclusin dan segregasi, dan

11. Tugas guru pembimbing khusus di sekolah inklusif

\section{PENUTUP}

\section{Simpulan}

Simpulan dalam penelitian ini terdari dari empat bagian penting yaitu:

1. Kompetensi pedagogik guru di sekolah inklusi menunjukkan nilai rata-rata (mean) 61,50 nilai terendah (minimum) 40 dan nilai tertinggi (maximum) 88 .

2. Terdapat perbedaan yang signifikan kompetensi pedagogik guru berdasarkan keikutsertaan pelatihan inklusi yang telah diikuti.

3. Kebutuhan guru dalam pelatihan tentang pendidikan inklusi menunjukkan $61 \%$ sangat perlu, $37 \%$ perlu, dan 3\% tidak perlu.

4. Identifikasi kebutuhan materi pelatihan pendidikan inklusi sebagai berikut 1) pengertian anak berkebutuhan khusus, 2) Jenis anak berkebutuhan khusus, karakteristik anak berkebutuhan khusus, 4) Identifikasi ABK, 5) adaptasi kurikulum bagi ABK, 6) Program Pembelajaran Individual (PPI), 7) Strategi pembelajaran bagi $\mathrm{ABK}$, 8) Evaluasi pembelajaran ABK, 9)Peraturan Menteri Pendidikan Nasional Nomor 70 tahun 2009, 10) Pengertian full inclusin dan segregasi, dan 11) tugas guru pembimbing khusus di sekolah inklusi.

\section{Saran}

1. Saran bagi Guru Inklusi a. Membentuk tutor sebaya untuk mendiskusikan permasalahan dan penanganan $\mathrm{ABK}$ di sekolah Inklusi

b. Mencari referensi mengenai ke PLB an dalam bentuk buku bacaan, bertanya pada ahli, dll.

c. Mengikuti kegiatan-kegiatan pendukung dalam meningkatkan kompetensi pedagogik ke PLB an berupa pelatihan, workshop dan seminar.

2. Saran bagi Sekolah

a. Membentuk tim inklusi sebagai pusat konsultasi Pendidikan inklusi di tingkat Sekolah

b. Memberikan pelatihan bagi guru dan tenaga administrasi mengenai ke PLB an di sekolah inklusi.

c. Menyediakan ruang sumber.

3. Saran bagi Pemerintah

a. Merencanakan pelatihanpelatihan ke PLB an secara rutin dan bertahap pada guru-guru di sekolah inklusi

b. Membuka layanan konsultasi sekolah inklusi

c. Membentuk Foruk Komunikasi (Forkom) Sekolah Inklusi tingkat Kabupaten.

\section{DAFTAR PUSTAKA}

Baley. (1982). Methods of Social Research. Edisi ke-2. New York: The Free Press.

Direktorat Jenderal Mandikdasmen. (2010). Permendiknas Tentang Pendidikan Inklusif Bagi Peserta Didik yang Memiliki Kelinan dan Memiliki Potensi 
Volume 3, No. 2 Januari 2020

Kecerdasan dan/atau Bakat Istimewa. Kementerian Pendidikan Nasional.

Elisa, S dan Wrastari, A.T. (2013). Sikap Guru Terhadap Pendidikan Inklusi Ditinjau dari Faktor Pembentukan Sikap. Jurnal Psikologi Perkembangan dan Pendidikan vol. 2 No. 1 hal. 52-61

Gay, L.R. dan Diehl, P.L. (1992), Research Methods for Business and. Management, New York: MacMillan Publishing Company.

Gunarhadi, Sunardi, Andayani, T.R., \& Anwar, M. (2016).Pedagogic mapping of teacher competence in inclusive schools. Prosiding ICTTE, 1 (1), 389-394

Narbuko, C \& Achmadi, A. (2002). Metodologi Penelitian. Jakarta : Bumi Aksara

Permendiknas No. 70 th 2009 tentang Pendidikan Inklusif Bagi anak yang memiliki kelainan dan memiliki potensi kecerdasan dan/atau bakat istimewa.

Sugiyono. (2014). Metode Penelitian Kuantitatif Kualitatif dan $R \& D$. Alfabeta: Bandung.

Undang-Undang Nomor. 4 Th. 1997 Tentang penyandang Cacat.

UUD 1945 (amandemen) pasal 31 ayat (1).

Yusuf, M. (2014). Evaluasi Diri Sekolah Inklusi. Surakarta: Tiga Serangkai

Yusuf, M. (2014). Manajemen Sekolah Berbasis Pendidikan Inklusif. Surakarta: Tiga Serangkai

Zainuddin A. (2000). Metode Penelitian. Program Pasca Sarjana Unair, Surabaya.

Zikmund, W. G. (1997). Business Research Methods. Fifth Edition. New York: The Dryden Press Harcourt Brace College Publishers. 